\title{
Strategi Pengembangan Potensi Pariwisata Di Pantai Blimbingsari, Kabupaten Banyuwangi
}

Melly Febriani Jayadi a, 1, Ida Bagus Suryawan a, 2

1 mellyfebrianij@gmail.com , 2 idabagussuryawan@unud.ac.id

a Program Studi S1 Destinasi Pariwisata, Fakultas Pariwisata,Universitas Udayana, Jl. Dr. R. Goris, Denpasar, Bali 80232 Indonesia

\begin{abstract}
Banyuwangi Regency is an area that has a variety of tourism potential either natural, cultural and artificial potential. One of the tourist attractions with its natural potential is Blimbingsari Beach. Blimbingsari Beach is one of the tourist attractions located in Banyuwangi Regency which is famous for its distinctive culinary fish. Currently tourists visit Blimbingsari Beach is still small compared to other tourist attractions. Tourism potential in Blimbingsari Beach is able to attract many tourists to visit by developing its tourist potential.

This study used primary data sources obtained directly by observation and interviews, and data analysis techniques used in this study is a SWOT analysis which is a qualitative analysis tool that is done by examining internal and external factors. SWOT analysis compares the external factors which are opportunities and threats with internal factors which are strengths and weaknesses. The results of this study shows that the development of Blimbingsari beach tourism potential can still be developed further through existing potential. Blimbingsari beach managers should promote more so that Blimbingsari beach is known to many people.
\end{abstract}

Keyword: Strategy Development, Potential, Blimbingsari Beach

\section{PENDAHULUAN}

Saat ini pariwisata merupakan primadona di seluruh dunia, kegiatan pariwisata merupakan kegiatan yang dapat mendatangkan manfaat dan keuntungan bagi negara-negara yang sebagai penerima kunjungan wisatawan, sehingga membuat sebagian negara di dunia begitupun dengan Indonesia, menganggap pariwisata merupakan sebuah aspek penting dari strategi pengembangan negara. Saat ini pariwisata merupakan salah satu penyumbang devisa terbesar bagi negara Indonesia. Hingga saat ini banyak wisatawan yang datang berkunjung ke Indonesia untuk menikmati potensi wisata yang tidak dapat ditemukan di negara mereka. Indonesia terkenal dengan budayanya yang kental yang menjadikan salah satu potensi wisata untuk menarik wisatawan datang berkunjung.

Indonesia memiliki semua potensi wisata yang ada, mulai dari wisata alam yaitu seperti pantai, hutan, dan pegunungan, wisata kebudayaan yang berupa adat istiadat, kesenian, maupun peninggalan sejarah dan yang terakhir yaitu wisata buatan manusia seperti pementasan seni tarian atau pertunjukkan budaya daerah masing masing. Setiap daerah yang ada di Indonesia saat ini mulai aktif menonjolkan keunggulan yang dimiliki oleh daerahnya untuk menjadikan Indonesia sebagai negara dengan destinasi wisata populer di dunia internasional.

Salah satu sektor pariwisata yang dimiliki oleh Indonesia ini berada di ujung Pulau Jawa yaitu Kabupaten Banyuwangi. Kabupaten Banyuwangi merupakan daerah yang memiliki berbagai macam potensi wisata baik potensi alam, budaya maupun buatan. Banyaknya daya tarik wisata yang bisa dikunjungi oleh wisatawan, jumlah kunjungan wisatawan domestik yang datang ke Kabupaten Banyuwangi pada tahun 2016 adalah sekitar 4,1 juta sedangkan wisatawan mancanegara sekitar 74 ribu dan ini telah meningkat dari tahun 2010 (Mahagangga dkk, 2008). Tidak hanya terkenal dengan potensi budaya dan alam seperti kesenian Gandrung dan Kawah Ijen, Kabupaten Banyuwangi juga memiliki potensi alam lainnya yaitu terdapat beragam pantai yang indah nan eksotis. Selain keindahan pantainya, terdapat berbagai aktivitas yang dapat dilakukan oleh wisatawan di kawasan pantai yang ada di Kabupaten Banyuwangi seperti sunset, snorkeling, surfing, kitesurf dan juga menyajikan kuliner seafood seperti Pantai Blimbingsari yang terletak di Kecamatan Rogojampi, berada sekitar 17 kilometer ke selatan dari pusat Kota Banyuwangi atau 1 kilometer dari bandara Blimbingsari. Pantai Blimbingsari merupakan salah satu daya tarik wisata yang berada di Kabupaten Banyuwangi yang terkenal dengan kuliner ikan bakarnya yang khas. Atraksi utama yang terdapat di Pantai Blimbingsari adalah pemandangan pantai, pasir hitamnya yang bertekstur lembut serta disana juga terdapat penyewaan kuda yang dapat disewa untuk menyusuri pesisir pantai, ditambah juga wisatawan dapat menikmati kuliner seafood 
yang sudah menjadi ciri khas Pantai Blimbingsari ini.

Saat ini kunjungan wisatawan ke Pantai Blimbingsari masih belum sesuai harapan, hal ini dikarenakan Pantai Blimbingsari masih tidak terlalu dikenal banyak wisatawan yang mengakibatkan rendahnya kunjungan wisatawan ke Pantai Blimbingsari. Dilihat dari potensi yang terdapat di Pantai Blimbingsari, Pantai Blimbingsari telah menarik wisatawan untuk berkunjung. Dalam rencana pengembangan dibutuhkan identifikasi potensi yang bisa dikembangkan serta bagaimana strategi pengembangannya. Dengan sedikitnya kunjungan wisatawan ke Pantai Blimbingsari, maka peneliti merasa perlu melakukan penelitian untuk membuat strategi pengembangan Pantai Blimbingsari dengan judul jurnal "Strategi Pengembangan Potensi Pariwisata di Pantai Blimbingsari Kabupaten Banyuwangi".

Dalam penelitian ini menggunakan beberapa konsep yaitu konsep strategi pengembangan (Yoeti, 1997), konsep potensi pariwisata (Pendit, 1999), konsep wisata bahari (Ditjen Pariwisata, 1998), konsep wisata kuliner (International Culinary Tourism Association/ICTA) dan konsep wisatawan (Undang-Undang No. 10 tahun 2009).

Pada penelitian ini diperlukan juga telaah penelitian sebelumnya, karena bertujuan untuk mengetahui perbandingan antara penelitian yang sebelumnya telah dilakukan dengan penelitian yang dilakukan saat ini, sehingga tidak terjadi penelitian yang ganda. Penelitian sebelumnya yang menjadi pembanding dalam penelitian ini yaitu yang pertama penelitian yang dilakukan oleh T. Prasetyo Hadi Atmoko (2014), dengan penelitian mengenai "Strategi Pengembangan Potensi Desa Wisata Brajan Kabupaten Sleman". Dalam penelitian ini memiliki fokus penelitian yang sama dengan penelitian yang dilakukan saat ini yaitu strategi pengembangan potensi wisata. Penelitian yang kedua dilakukan oleh Sofyan Azwar Anas (2011), yang penelitian mengenai "Dampak Kebijakan Pariwisata Pada Peningkatan Ekonomi Masyarakat Kabupaten Banyuwangi (Studi di Desa Blimbingsari Kec. Rogojampi Kab. Banyuwangi )". Dalam penelitian ini memiliki lokus yang sama dengan penelitian yang dilakukan saat ini yaitu dilaksanakan di Desa Blimbingsari, Kecamatan Rogojampi, Kabupaten Banyuwangi.

Perbedaan penelitian ini dengan penelitian lainnya adalah lokasi penelitian yang diangkat merupakan lokasi penelitian yang masih sedikit diteliti terutama dalam bidang pariwisata, dan lokasi penelitian ini merupakan pantai yang memiliki banyak potensi namun masih sedikit wisatawan yang datang berkunjung sehingga penelitian ini sangat penting dilakukan untuk meningkatkan kunjungan wisatawan ke Pantai Blimbingsari.

\section{METODE PENELITIAN}

Ruang lingkup dalam penelitian ini adalah strategi pengembangan potensi wisata yaitu potensi alam, potensi budaya, atraksi, dan fasilitas. Lokasi penelitian yang dilakukan dalam penelitian ini berada di Pantai Blimbingsari, Desa Blimbingsari, Kecamatan Rogojampi, Kabupaten Banyuwangi. Penelitian ini dilaksanakan selama kurang lebih 1 bulan.

Jenis data yang digunakan dalam penelitian ini berupa jenis data kualitatif (Moleong, 2000) dan data kuantitatif (Sugiyono, 2007) dengan sumber data yaitu sumber data primer (Sugiyono, 2007) dan sumber data sekunder (Sugiyono, 2007). Sumber data primer yang diperoleh dalam penelitian ini adalah potensi wisata yang terdapat di Pantai Blimbingsari, atraksi yang tersedia, fasilitas serta transportasi. Pengumpulan data dalam penelitian ini dilaksanakan dengan cara observasi (Bungin, 2007) dan wawancara (Bungin, 2007) yang dilakukan langsung dengan Kepala Desa Blimbingsari dan masyarakat yang terdapat di Desa Blimbingsari. Dalam penelitian ini, data yang sudah dikumpulkan diolah dan dianalisis secara deskriptif dengan alat analisis SWOT yang merupakan alat analisis kualitatif yang dilakukan dengan mengkaji faktor - faktor internal dan eksternal. Faktor internal dalam hal ini adalah Strength (kekuatan) dan Weakness (kelemahan), sedangkan faktor eksternal dalam hal ini adalah Opportunity (peluang) dan Threat (ancaman) (Rangkuti, 2008).

\section{HASIL DAN PEMBAHASAN}

\section{A. Pantai Blimbingsari}

Desa Blimbingsari terletak dipesisir timur Pulau Jawa yang mayoritas penduduknya memiliki mata pencaharian sebagai petani dan nelayan. Mayoritas penduduk yang terdapat di desa ini berasal dari empat suku yaitu Osing, Jawa, Bali dan Madura. Penelitian ini dilakukan di Pantai Blimbingsari, Desa Blimbingsari, Kecamatan Rogojampi, Kabupaten Banyuwangi. Pantai Blimbingsari tepatnya berada sekitar 17 kilometer ke selatan dari pusat Kota Banyuwangi yang berdekatan dengan Bandara Blimbingsari, yaitu sekitar 1 (satu) kilometer dari sebelah Timur Bandara Blimbingsari. Pantai Blimbingsari merupakan tempat yang sangat strategis bagi 
wisatawan yang ingin menikmati hidangan kuliner ikan bakar. Pantai ini memiliki panjang 175 Kilometer.

\section{Gambar 1}

Peta Pantai Blimbingsari

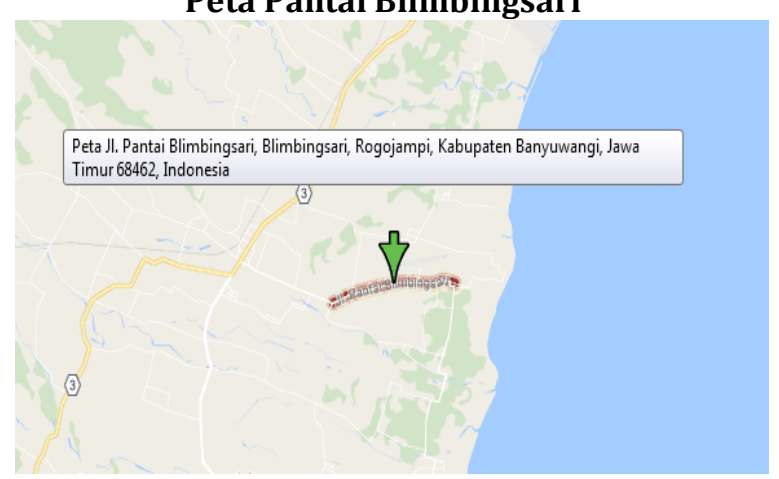

Sumber : Google Maps

Akses untuk menuju Pantai Blimbingsari ini terbilang cukup mudah dan memadai, jika wisatawan tidak mempunyai kendaraan pribadi, wisatawan dapat menggunakan dokar (andong) yang biasa terdapat di pasar Rogojampi, sehingga sepanjang perjalanan menuju pantai bisa menikmati pemandangan hamparan sawah yang tak kalah menariknya. Dengan adanya alternatif transportasi dokar ini, wisatawan tidak perlu cemas bila ingin berkunjung ke wisata alam Pantai Blimbingsari.

Pantai Blimbingsari merupakan salah satu destinasi wisata unggulan di Kabupaten Banyuwangi karena memiliki wisata kuliner yang khas yaitu masakan yang berbahan dasar hasil laut terutama ikan bakar. Kelezatan ikan bakar yang disajikan di Pantai Blimbingsari memiliki cita rasa yang khas sehingga telah dikenal hingga diluar pulau Banyuwangi. Selain menawarkan kelezatan kuliner seafood nya, Pantai Blimbingsari juga menyuguhkan pemandangan laut yang sangat mempesona. Pantai Blimbingsari merupakan pantai yang bersih dengan hamparan pasir hitam yang lembut dan deburan ombak yang tenang sehingga membuat pantai ini ramai dikunjungi oleh wisatawan lokal maupun mancanegara. Pada awalnya Pantai Blimbingsari merupakan tempat parkir bagi perahu para nelayan, namun seiring berjalannya waktu, Pantai Blimbingsari mulai dikunjungi oleh wisatawan karena pesona yang disajikan oleh pantai ini. Karena Pantai Blimbingsari mulai diminati dan ramai dikunjungi oleh wisatawan maka penduduk sekitarpun melihat peluang untuk membuat usaha yaitu dengan mendirikan rumah makan yang menyajikan makanan khas berbahan dasar olahan hasil laut, salah satunya berkat berdirinya warung lesehan sejak tahun 1998 lalu. Dulunya, warung-warung itu adalah rumah yang pemiliknya bekerja sebagai nelayan. Ide mendirikan warung hanya karena coba-coba. Saat itu, sebagian ikan dari tangkapannya dibakar lalu dijual ke tetangga. Lambat laun, makanan berbahan dasar olahan hasil laut ini bertambah laris dan hingga saat ini banyak penduduk lokal yang membuka usaha rumah makan disekitar pantai, maka dari itu Pemerintah Kabupaten Banyuwangi pun mulai membangun infrastruktur penunjang dan memperbaiki akses menuju Pantai Blimbingsari sehingga memudahkan wisatawan yang ingin datang berkunjung. Menikmati keindahan Pantai Blimbingsari dengan menyantap kelezatan hidangan hasil olahan laut menjadi ikon bagi Pantai Blimbingsari. Satu hal yang menjadi ciri khas hidangan yang disajikan di Pantai Blimbingsari ini berbeda dengan hidangan laut di pantai-pantai lainnya adalah media yang digunakan oleh pemilik rumah makan di Pantai Blimbingsari untuk membakar ikan bukanlah arang melainkan pecahan batok kelapa. Alasan utama para pemilik rumah makan menggunakan pecahan batok kelapa adalah bila dibakar maka tidak akan ada jelaga yang menempel pada hasil ikan bakarnya berbeda dengan jika menggunakan arang sebagai media untuk membakar ikan tersebut.

Tidak hanya keindahan hamparan pantai dan kelezatan hidangan lautnya, para wisatawan juga dapat menikmati Pantai Blimbingsari dengan menunggangi kuda yang disewakan oleh penduduk sekitar dan berjalan jalan disekitar Pantai Blimbingsari. Hal ini tentu menjadi daya tarik tersendiri bagi wisatawan yang berkunjung. Mata pencaharian mayoritas masyarakat yang terdapat di Desa Blimbingsari adalah petani dan nelayan. Karena terdapat hamparan sawah yang membentang luas, menjadikan peluang bagi masyarakat disana untuk menjadi petani. Desa Blimbingsari memiliki sebuah pantai yaitu Pantai Blimbingsari yang terkenal dengan olahan bahan hasil lautnya yang menjadikan mayoritas masyarakat Desa Blimbingsari bekerja sebagai nelayan, dimana terdapat beberapa nelayan yang mendirikan rumah makan dan menyajikan hasil tangkapan lautnya.

\section{B. Potensi Wisata Pantai Blimbingsari}

Pantai Blimbingsari memiliki potensi alam yang dapat dijadikan daya tarik bagi wisatawan untuk berkunjung. Kondisi alam yang terdapat di Pantai Blimbingsari masih asri namun terlihat masih terdapat sampah di sepanjang bibir pantai, sepanjang perjalanan menuju Pantai Blimbingsari terdapat hamparan sawah di kanan dan kiri jalannya yang menjadikan suasana di tempat ini sejuk, begitu pula apabila wisatawan telah sampai di Pantai Blimbingsari akan disuguhkan pemandangan pantai yang indah 
dengan hamparan pasir hitamnya yang berkilau. Jika wisatawan berkunjung pada pagi hari, akan terdapat banyak nelayan yang pergi menangkap ikan ke tengah laut menggunakan kapal, dimana kapal tersebut akan diparkir di pinggir pantai sesudahnya.

Desa Blimbingsari memiliki festival tahunan Petik Laut yang diadakan setahun sekali setiap Bulan Suro yang bertempat di Pantai Blimbingsari. Acara tersebut diadakan tidak menentu karena mengikuti penanggalan adat Jawa. Namun, dua puluh hari sebelum festival berlangsung akan ada pemberitahuan dari Kepala Desa kepada masyarakat. Festival itu diadakan selama dua hari yaitu hari sabtu dan minggu. Pada jaman dahulu dalam acara tersebut akan diadakan melarung hewan. Tetapi untuk sekarang ini tokoh masyarakat dan ulama desa melarang hal tersebut karena dianggap musrik sehingga hanya diadakan pertunjukan kesenian saja. Dalam festival tersebut mayoritas yang menyaksikan adalah masyarakat lokal itu sendiri, serta pernah terlihat beberapa wisatawan mancanegara.

Pantai Blimbingsari memiliki beberapa atraksi yang dapat dinikmati oleh para wisatawan yang sedang berkunjung disana. Salah satu cara menikmati keindahan Pantai Blimbingsari adalah terdapat penyewaan kuda milik masyarakat setempat. Kuda yang disewa dapat menemani wisatawan mengelilingi pantai dengan menikmati panorama yang ada. Sebagian dari kuda-kuda tersebut dihias sedemikian rupa dengan pernak-pernik berwarna-warni serta ada sebagian kuda lagi yang dihias seperti andong sehingga menarik wisatawan agar mau menaiki kuda tersebut. Penyewaan kuda mulai beroperasi dari pukul 14.00 siang sampai pukul 18.00 sore. Jika hari libur, penyewaan kuda sudah bisa dijumpai dari pukul 07.00 pagi sampai pukul 19.00 malam. Untuk wisatawan dewasa biaya yang dikenakan sebesar Rp $10.000,00$ sedangkan anak-anak dikenakan biaya sebesar Rp 5.000,00 (Sumber: Wawancara Peneliti, 2017) Selain atraksi tersebut, kapal para nelayan yang tersusun rapi juga menjadi daya tarik tersendiri bagi para wisatawan yang berkunjung di pantai tersebut. Karena mayoritas penduduk desa bermata pencaharian sebagai nelayan, kapal - kapal yang menepi dan terparkir di pinggiran pantai memberikan daya tarik tersendiri bagi wisatawan. Kapal dengan cat berwarna-warni yang menepi di pinggir pantai tersusun dengan rapi sehingga dapat menjadi spot bagi para wisatawan untuk mengambil beberapa foto disana.

Pantai Blimbingsari memiliki beberapa fasilitas pendukung seperti toilet umum yang berada disebelah pos pengamanan TNI-AL dengan dipungut biaya $\mathrm{Rp} 2.000,00$. Toilet umum yang kedua berada di tengah deretan warung - warung penjual makanan dan minuman. Toilet umum yang terdapat di Pantai Blimbingsari ini kondisinya tidak terlalu buruk namun masih bisa untuk digunakan. Adanya tempat parkir juga merupakan salah satu fasilitas yang disediakan di Pantai Blimbingsari. Lahan parkir yang luas membuat wisatawan tidak berebut lahan parkir sehingga wisatawan dapat dengan mudah memarkir kendaraannya. Adanya pengutipan karcis masuk ke daya tarik wisata Pantai Blimbingsari diadakan mulai pukul 16.00 WIB. Pemberian karcis dilakukan di pintu masuk Pantai Blimbingsari dengan biaya Rp 2.000,00 bagi kendaraan roda dua, $\mathrm{Rp} 3.000,00$ kendaraan roda empat, dan Rp 10.000,00 jika wisatawan yang berkunjung menggunakan bus besar. Biaya masuk sendiri tidak dihitung melalui jumlah wisatawannya melainkan dari kendaraan yang digunakan dan yang terparkir.

Pantai Blimbingsari terkenal dengan wisata kulinernya. Sebagian besar mata pencaharian masyarakat Desa Blimbingsari adalah nelayan. Karena hasil laut yang didapat itulah istri dari para nelayan membuka warung dan menjual hasil laut yang didapat oleh suaminya dengan menjadikannya olahan ikan bakar. Dengan adanya warung-warung tersebut dapat memenuhi kebutuhan wisatawan jika wisatawan ingin makan atau minum. Mereka dapat singgah diwarung untuk sekedar mencicipi hasil laut segar yang disediakan atau memilih makanan yang diinginkan.

Selain itu, di Pantai Blimbingsari juga terdapat beberapa tempat duduk seperti gazebo yang terdapat di depan warung warung lesehan dan wisatawan bisa duduk disana untuk sekedar bersantai ataupun menikmati pemandangan yang ada di Pantai Blimbingsari.

\section{Strategi Pengembangan Potensi Wisata Pantai Blimbingsari}

Dalam merumuskan strategi pengembangan di Pantai Blimbingsari, tahap yang dilakukan pertama adalah melihat komponen produk yang terdapat di Pantai Blimbingsari, setelah itu identifikasi faktor internal dan faktor eksternal. Adapun yang dimaksud dengan faktor internal adalah penjabaran kekuatan dan kelemahan, sedangkan faktor eksternal adalah penjabaran peluang dan ancaman. Berikut adalah penjabaran dari masing-masing faktor:

\section{Faktor Internal}

Faktor internal ini merupakan identifikasi apa saja aspek-aspek pengembangan dari 
dalam Pantai Blimbingsari. Aspek-aspek tersebut berupa kekuatan dan kelemahan yang ada, faktor ini nantinya akan digunakan untuk merumuskan strategi pengembangan dalam analisis SWOT. Berikut adalah penjabaran dari masing-masing aspek;

A. Strength (kekuatan)

Kekuatan yang dimaksud dalam faktor internal merupakan potensi yang berasal dari Pantai Blimbingsari. Adapun kekuatan yang dimaksud adalah sebagai berikut;

a. Potensi alam dan budaya yang dapat dijadikan sebagai atraksi wisata.

b. Aksesibilitas menuju Pantai Blimbingsari sudah baik dan memadai

c. Wisatawan dapat memancing ikan di pantai

B. Weaknesses (kelemahan)

Kelemahan yang dimaksud dalam faktor internal merupakan kekurangan yang mengakibatkan kegiatan yang dilakukan kurang maksimal. Adapun kelemahan yang dimaksud adalah sebagai berikut.

a. Fasilitas untuk penunjang kegiatan pariwisata kurang memadai

b. Promosi yang dilakukan masih dalam lingkup kecil

\section{Faktor Eksternal}

Faktor eksternal ini merupakan identifikasi aspek-aspek apa saja yang terdapat dalam pengembangan dari luar Pantai Blimbingsari. Aspek-aspek tersebut berupa peluang dan ancaman yang ada, faktor ini nantinya juga akan digunakan untuk merumuskan strategi pengembangan Pantai Blimbingsari dalam analisis SWOT. Berikut adalah penjabaran dari masing-masing aspek;

A. Opportunities ( peluang)

Peluang yang dimaksud dalam faktor eksternal merupakan faktor dari luar yang dapat memberikan dampak positif serta yang mampu mendukung kegiatan pariwisata. Adapun peluang yang dimaksud adalah sebagai berikut

a. Terdapat forum muda mudi yang dapat dibentuk sebagai pokdarwis

b. Aksesibilitas, Pantai Blimbingsari berdekatan dengan Bandara Blimbingsari dan dekat dengan pusat kota

\section{B. Threats (ancaman)}

Ancaman yang dimaksud dalam faktor ekstrenal merupakan faktor dari luar yang dapat memberikan dampak negatif terhadap kegiatan pariwisata atau dapat juga dikatakan sebagai penghambat kegiatan. Adapun ancaman yang dimaksud adalah sebagai berikut :

a. Kurangnya atraksi yang terdapat di Pantai Blimbingsari

b. Pelayanan fasilitas yang kurang memadai

Dari identifikasi faktor Strenght, Weakness, Opportunities dan Threats dapat dirumuskan strategi pengembangan Pantai Blimbingsari sebagai berikut :

1. Strategi SO (Strength Opportunities)

Strategi SO adalah strategi yang menggunakan kekuatan untuk memanfaatkan peluang. Berdasarkan hal tersebut maka dihasilkan strategi SO dalam pengembangan Pantai Blimbingsari adalah sebagai berikut;

a. Memanfaatkan potensi alam dan budaya untuk dijadikan atraksi wisata guna menarik kunjungan wisatawan.

Pantai Blimbingsari memiliki potensi alam dan budaya yang dapat dijadikan sebagai atraksi wisata bagi wisatawan yang datang berkunjung, Pantai Blimbingsari memiliki pasir pantai berwarna hitam yang berkilau dan menjadikan suatu daya tarik tersendiri bagi wisatawan. Pantai ini juga menyuguhkan pemandangan pantai yang asri yang dapat dinikmati sembari menikmati hasil olahan laut ataupun sambil memancing. Desa Blimbingsari memiliki festival tahunan yang bernama Petik Laut yang rutin diadakan setahun sekali pada bulan suro, biasanya dua puluh hari sebelum acara dilaksanakan, akan dilakukan promosi dan pemberitahuan agar wisatawan dapat berkunjung. Dengan letak Pantai Blimbingsari yang cukup strategis yaitu dekat dengan Bandara Blimbingsari dapat menjadikan suatu keuntungan karena wisatawan dapat datang berkunjung untuk melepas penat.

b. Memelihara akses yang sudah tersedia dengan baik agar memudahkan wisatawan yang berkunjung

Akses yang tersedia dan dapat ditempuh dengan baik menuju Pantai Blimbingsari perlu dipelihara dan dijaga untuk berlangsungnya kegiatan pariwisata, karena akses juga merupakan komponen penting dalam pariwisata. Untuk memelihara akses yang sudah baik tersebut, dapat dilakukan dengan cara menjaga kebersihan jalur desa secara gotong royong. Transportasi yang dapat digunakan untuk berkunjung adalah kendaraan roda dua, mobil, minibus serta bus pariwisata apabila terdapat wisatawan yang berkunjung dalam jumlah yang banyak. Selain itu keamanan dan kenyamanan di sekitar pantai perlu diperhatikan 
karena hal tersebut juga merupakan faktor penting. Hal lainnya yang perlu diperhatikan adalah perlu penambahan penerangan atau lampu untuk sepanjang jalan menuju pantai karena penerangan dijalanan masih minim dan dapat membahayakan pengendara pada malam hari. Selain transportasi dan akses, penunjuk arah juga perlu dipertegas agar wisatawan yang datang berkunjung secara individu dapat dengan mudah menemukan Pantai Blimbingsari.

c. Membuat atraksi wisata memancing

Pantai Blimbingsari terkenal dengan kuliner hasil olahan lautnya, pada pagi hari para nelayan akan menangkap ikan ke tengah laut dan siang harinya akan langsung dijual oleh istrinya di tempat makan lesehan yang ada disekitar pantai. Dengan adanya hal ini, dapat menjadikan memancing sebagai atraksi yang baru, pihak desa perlu memfasilitasi wisatawan ataupun pengunjung yang ingin memancing di pantai dengan menyediakan penyewaan alat pancing sehingga wisatawan yang memiliki hobi memancing dapat menyalurkan hobinya dengan mudah. Selain itu fasilitas lainnya seperti toilet, tempat sampah dan lainnya perlu ditingkatkan lagi kualitasnya. Kebersihan toilet perlu ditingkatkan serta perlu penambahan tempat sampah.

\section{Strategi WO (Weaknesess Opportunities)}

Strategi WO adalah strategi yang diciptakan untuk meminimalkan kelemahan dengan memanfaatkan peluang yang tersedia. Berdasarkan hal tersebut maka dihasilkan strategi WO dalam pengembangan Pantai Blimbingsari adalah sebagai berikut;

a. Membentuk pokdarwis dari forum muda mudi

Desa Blimbingsari memiliki sebuah forum atau perkumpulan pemuda pemudi yang memiliki jumlah pengikut di media sosial berkisar 13 ribu keatas. Mereka akan dikumpulkan setiap satu bulan sekali dan diminta untuk mempromosikan Pantai Blimbingsari. Kepala Desa mengumpulkan para pemuda-pemudi tersebut di kantor Desa Blimbingsari lalu diberikan paket internet secara gratis dan diajak minum kopi bersama lalu Kepala Desa akan memaparkan beberapa materi tentang Pantai Blimbingsari serta informasi yang akan di upload ke media sosial masing-masing para pemuda-pemudi tersebut. Hal ini sudah bagus dilakukan untuk mempromosikan Pantai Blimbingsari. Kepala Desa bisa membentuk sebuah pokdarwis melalui forum muda mudi tersebut agar dapat lebih mengembangkan wisata Pantai Blimbingsari dan membuat pengelolaan lebih terstruktur. b. Melakukan promosi dan menjalin kerjasama dengan travel agent

Pengelola Pantai Blimbingsari perlu melakukan kerjasama dengan travel agent, dengan jarang Pantai Blimbingsari yang dekat dengan Bandara Blimbingsari dapat memudahkan pihak travel agent untuk membawa wisatawan berkunjung ke Pantai Blimbingsari. Adanya kerjasama dengan pihak travel mampu membantu mempromosikan Pantai Blimbingsari. Selain itu cara lain untuk promosi bisa menggunakan brosur, Pantai Blimbingsari bisa dicantumkan dalam brosur daya tarik wisata Kabupaten Banyuwangi dimana brosur tersebut dapat ditemukan di Tourist Information Centre. Alternatife promosi melalui media sosial sudah diterapkan dengan baik oleh pihak Kepala Desa karena saat ini media sosial sangat berperan dalam mempromosikan Pantai Blimbingsari.

3. Strategi ST (Strength Threats)

Strategi ST adalah strategi yang diciptakan dengan memanfaatkan kekuatan yang ada untuk mengatasi ancaman. Berdasarkan hal tersebut maka dihasilkan strategi ST dalam pengembangan Pantai Blimbingsari adalah sebagai berikut;

a. Memperlihatkan daya tarik yang ada dari potensi yang dapat dikembangkan

Dalam mengembangkan potensi yang sudah ada di Pantai Blimbingsari, daya tarik potensi harus bisa diperlihatkan, pengelola Pantai Blimbingsari harus mengetahui hal tersebut karena daya tarik tersebut merupakan nilai tambah didalam potensi yang bisa dijadikan atraksi wisata guna menarik kunjungan wisatawan. Sehingga jika ada daerah lain yang menawarkan atraksi yang sama masih dapat untuk bersaing dengan daerah lainnya.
b. Membangun beberapa fasilitas penunjang seperti penginapan, toko oleh oleh, dan lain lain

Pantai Blimbingsari memerlukan beberapa penginapan maupun homestay yang dapat di bangun di Desa Blimbingsari agar memudahkan wisatawan yang ingin menginap di daerah tersebut. Toko oleh oleh maupun souvenir juga perlu dibuka untuk wisatawan agar dapat membeli cinderamata khas Pantai Blimbingsari.

\section{Strategi WT (Weaknesess Threats)}

Strategi WT adalah sebuah strategi yang diciptakan untuk meminimalkan kelemahan untuk menghindari ancaman yang ada. Berdasarkan hal tersebut maka dihasilkan strategi WT dalam pengembangan Pantai Blimbingsari adalah sebagai berikut; 
a. Mengadakan penyuluhan atau pelatihan tentang pariwisata kepada masyarakat

Sasaran yang dilakukan dalam penyuluhan ataupun pelatihan tentang pariwisata adalah masyarakat lokal Desa Blimbingsari. Hal ini dilakukan karena masyarakat merupakan salah satu sumber daya dalam kegiatan pariwisata. Meskipun tidak dipelajari secara mendalam diharapkan masyarakat lebih mengerti mengenai keramah tamahan yang dirasa perlu untuk ditunjukkan kepada wisatawan. Selain itu, masyarakat juga perlu mengetahui tentang keadaan desa, sejarah atau hal lainnya yang berkaitan dengan daerahnya sendiri.

b. Menjaga kelestarian potensi yang ada

Masyarakat perlu menjaga potensi yang telah ada di Pantai Blimbingsari, diharapkan agar rutin melakukan pembersihan sampah disekitar pesisir pantai agarpantai dapat selalu bersih. Masyarakat senantiasa harus selalu menjaga potensi alam dan budaya yang telah ada karena dengan tujuan melalui pariwisata diharapkan masyarakat dapat menjaga dan melestarikan potensi alam dan budaya. Melestarikan yang dimaksud dalam hal ini adalah potensi alam maupun budaya yang sudah ada dikembangkan tanpa harus merubah keaslian yang ada dari potensi tersebut.

Pantai Blimbingsari memiliki potensi alam yang dapat dinikmati oleh wisatawan yang datang berkunjung seperti pantai dengan hamparan pasir hitam yang bersih dan deburan ombak yang dapat dinikmati oleh wisatawan sembari menikmati hasil olahan laut ikan bakar yang dijual di warung sekitar pantai. Strategi pengembangan dalam menjaga potensi alam yangtelah ada yaitu dengan menjaga kebersihan pantai dari sampah dengan cara rutin melakukan gotong royong dan menyediakan banyak tempat sampah di sekitar pantai.

Desa Blimbingsari memiliki festival tahunan yang bernama Petik Laut. Festival ini rutin diadakan di Pantai Blimbingsari setiap satu tahun sekali. Festival ini dapat menarik wisatawan untuk datang berkunjung ke Pantai Blimbingsari karena festival ini akan menampilkan berbagai pentas kesenian.

Terdapat beberapa atraksi wisata yang dapat dinikmati oleh wisatawan di Pantai Blimbingsari seperti hamparan pasir hitam, kumpulan perahu nelayan yang berjejer serta terdapat penyewaan kuda untuk mengelilingi pantai di sore hari. Terdapat atraksi yang dapat dikembangkan di Pantai Blimbingsari seperti memancing. Hal ini dapat dijadikan sebagai lapangan kerja baru bagi masyarakat Desa Blimbingsari dengan menyewakan alat pancing dan menjual umpan untuk memancing agar wisatawan dapat menyalurkan hobinya.

Pantai Blimbingsari memiliki beberapa fasilitas yang dapat digunakan oleh wisatawan seperti toilet, gazebo di pinggir pantai, lahan parkir yang luas, spot foto menarik serta warung makan dengan olahan hasil laut yang khas Pantai Blimbingsari. Fasilitas tambahan yang perlu dibangun ialah toko souvenir dan penginapan. Masyarakat Desa Blimbingsari dapat membuat oleh oleh buatan tangan yang menjadi ciri khas pantai tersebut untuk dijadikan cinderamata oleh wisatawan.

\section{KESIMPULAN}

Pantai Blimbingsari merupakan pantai yang indah dengan hamparan pasir hitamnya. pantai ini memiliki daya tarik tersendiri karena deburan ombaknya yang keras dan menenangkan. Pantai Blimbingsari memiliki satu festival tahunan yang bernama Festival Petik Laut yang dilaksanakan di setiap Bulan Suro dimana dalam festival ini akan menampilkan pentas kesenian yang diadakan selama dua hari yaitu hari sabtu dan minggu. Di Pantai Blimbingsari wisatawan dapat menemukan penyewaan kuda yang terdapat banyak hiasan menarik dengan harga sewa yang terjangkau. Pantai ini berkembang dalam bidang wisata kuliner. Terdapat sekitar 15 warung lesehan yang menyajikan menu makanan olahan ikan bakar yang menjadi daya tarik utama di Pantai Blimbingsari ini. Akses jalanan yang di lewati untuk menuju Pantai Blimbingsari sudah cukup bagus dan tidak rusak namun saat memasuki daerah Desa Blimbingsari kurang adanya penerangan di pinggir jalan. Fasilitas yang diberikan oleh Pantai Blimbingsari masih terbilang minim, disini hanya terdapat lahan untuk parkir, toilet umum yang di pungut biaya dua ribu rupiah, dan tempat duduk seperti gazebo. Pantai Blimbingsari saat ini masih dikelola oleh Desa Blimbingsari itu sendiri dan dibantu oleh TNI AL untuk menjaga keamaan Pantai Blimbingsari.

Saran yang dapat diberikan adalah tetap menjaga kelestarian dan kebersihan lingkungan Pantai Blimbingsari. Melakukan promosi menarik yang dapat dilihat oleh banyak orang untuk datang berkunjung ke Pantai Blimbingsari. Menambah beberapa pertunjukan maupun aktifitas lainnya saat berlangsung festival petik laut seperti stand makanan. Menambah atraksi wisata di Pantai Blimbingsari agar banyak terdapat kegiatan yang dapat dinikmati oleh wisatawan yang berkunjung seperti spot-spot foto menarik, melukis dinding agar lebih estestik dan penyewaan sepeda untuk berkeliling pantai. 
Terakhir yaitu melakukan beberapa penataan warung makan agar terlihat lebih rapi dan memberikan papan nama pada warung, serta meningkatkan kreatifitas dengan membuat kerajinan tangan yang dapat dijual untuk dijadikan sebagai oleh oleh bagi wisatawan.

\section{DAFTAR PUSTAKA}

Anonim. 2009. Undang - Undang RI no 10 Tahun 2009 Tentang Kepariwisataan

Anas, S.A., 2011. Dampak Kebijakan Pariwisata Pada Peningkatan Ekonomi Masyarakat Kabupaten Banyuwangi (Studi di Desa Blimbingsari Kec. Rogojampi Kab. Banyuwangi) (Doctoral dissertation, University of Muhammadiyah Malang).

Anonimous, Dirjen Pariwisata RI, Pariwisata Nusantara Indonesia, Jakarta, 1998.

Atmoko, T.P.H., 2014. Strategi Pengembangan Potensi Desa Wisata Brajan Kabupaten Sleman.Jurnal Media Wisata: Wahana Informasi Pariwisata, 12(2).

Besra, E., 2015. Potensi wisata kuliner dalam mendukung pariwisata di kota Padang. JRAB: Jurnal Riset Akuntansi \& Bisnis, 12(1).

Bungin, Burhan. 2007. Penelitian Kualitatif Komunikasi, Ekonomi, Kebijakan Publik, dan Ilmu Sosial lainnya. Jakarta : Prenada Media Group

Eastjava.com. Pantai Blimbingsari. https://www.eastjava.com/eastjava/tourism/banyuwangi/ina/pulau_sa nten_beach.html. Diakses pada tanggal 12 November 2019

Ihategreenjello.com. Pesona Keindahan Pantai Blimbingsari Banyuwangi. https://ihategreenjello.com/pesonakeindahan-pantai-blimbingsari/Diakses pada tanggal 12 November 2019

Mahagangga, I Gusti Agung, Suryawan, Ida Bagus, Anom, I Putu, Kusumanegara, I Made. 2008. Evolusi Priwisata di Indonesia, Turismemorfosis di Kabupaten Badung, Kabupaten Banyuwangi dan Kabupaten Luwu Timur. Denpasar : Cakra Media Utama

Moleong, Lexy J. 2000. Metodelogi Penelitian Kualitatif. Bandung: PT. Remaja Rosdakarya

Pendit, Nyoman S. 1999. Ilmu Pariwisata Sebuah Pengantar Perdana. Jakarta: PT. Pradnya Paramita

Rangkuti, Freddy. 2003. Analisis SWOT Teknik Membedah Kasus Bisnis. Jakarta: Penerbit PT Gramedia Pustaka Utama.

Sugiyono. 2007. Metode Penelitian Kuantitatif, Kualitatif, dan R\&D. Bandung : Alfabeta
Telusurindonesia.com. Menikmati Tempat Wisata Pantai Blimbingsari Banyuwangi dengan Ikan Bakarnya. http://www.telusurindonesia.com/meni kmatitempat-wisata-pantaiblimbingsaribanyuwangi-dengan-ikanbakarnya.html. Diakses pada tanggal 12 November 2019

Wisatadanbudaya.com. Wisata Pantai Juga Wisata Kuliner. http://wisatadanbudaya.blogspot.com/2 010/10/pantai-blimbingsari.html.

Diakses pada tanggal 12 November 2019

Yoeti, Oka A. 2008. Perencanaan dan Pengembangan Pariwisata. Jakarta: PT. Pradnya Paramita

Yustinaningrum, D., 2017. Pengembangan Wisata Bahari Di Taman Wisata Perairan Pulau Pieh Dan Laut Sekitarnya. Agrika, 11(1). 